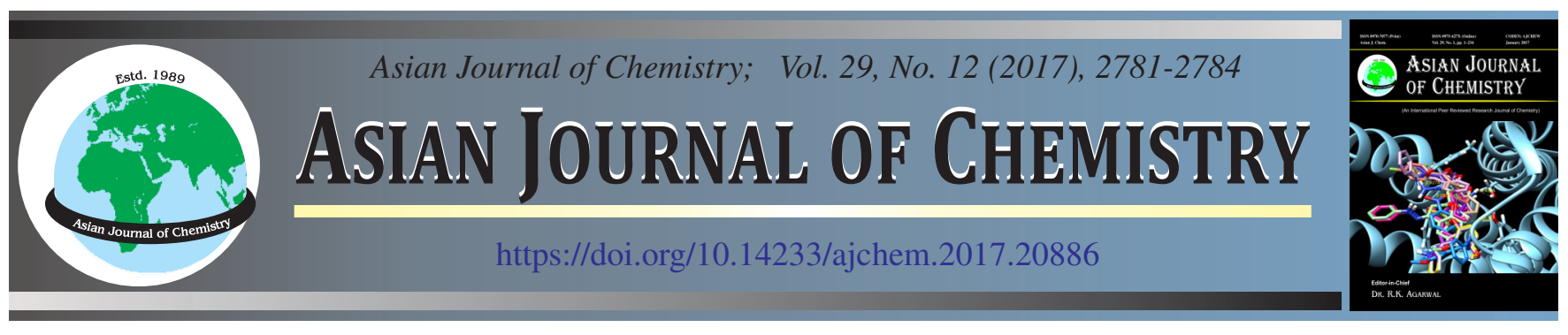

\title{
Viscometric and Thermodynamics Study of Bi-Univalent Mixed Electrolytes in Aqueous Solutions at 293.15, 303.15 and 313.15 K
}

\author{
Durgesh Gautam*, Varsha Sharma and Mukhtar Singh
}

Department of Chemistry, Agra College, Agra-282 002, India

*Corresponding author: E-mail: dgautamchem@gmail.com

Viscosities $(\eta)$ and apparent molar volumes $\left(\mathrm{V}_{\phi}\right)$ of the solutions of bi-univalent mixed electrolytes in aqueous solutions have been determined at 293.15, 303.15and 313.15 K. From these data the values of coefficients A and B of Jones-Dole equation and that of $\mathrm{V}_{\phi}{ }^{0}$ and $\mathrm{S}_{\mathrm{v}}$ of Masson's equation have been obtained. Besides the activation thermodynamic quantities $\Delta \mu_{2}{ }^{0 \#}, \Delta \mathrm{H}_{2}{ }^{0 \#}$ and $\Delta \mathrm{S}_{2}{ }^{0 \#}$ of viscous flow have also been calculated. The variation of $\phi_{\mathrm{v}}$ with $\mathrm{y}$, fraction of ionic strength due to the first electrolyte in the mixture of two electrolytes at different temperatures is linear. From $\eta$ and $\phi_{\mathrm{v}}$ data, the values of coefficients $\mathrm{A}$ and B of Jones-Dole equation and that of $\mathrm{V}_{\phi}{ }^{0}$ and $\mathrm{S}_{\mathrm{v}}$ of Masson's equation have been obtained. Besides the activation thermodynamic quantities $\Delta \mu_{2}{ }^{0 \#}, \Delta \mathrm{H}_{2}{ }^{0 \#}$ and $\Delta \mathrm{S}_{2}{ }^{0 \#}$ of viscous flow have also been calculated for the mixed electrolytes in aqueous solutions. It is seen that the values of $\Delta \mu_{2}{ }^{0 \#}$ are much larger as compared to those of $\Delta \mu_{1}{ }^{0 \#}$ for all the bi-univalent mixed electrolytes. The values of $\mathrm{T} \Delta \mathrm{S}_{2}{ }^{0 \#}$ are negative while those of $\Delta \mathrm{H}_{2}{ }^{0 \#}$ are positive and that $\Delta \mathrm{H}_{2}{ }^{0 \#}>\mathrm{T} \Delta \mathrm{S}_{2}{ }^{0 \#}$. Thereby suggesting that ion-solvent interaction for the mixed electrolyte system, are nearly complete in the ground state. Further these the values of $\mathrm{T} \Delta \mathrm{S}_{2}{ }^{0 *}$ and $\Delta \mathrm{H}_{2}{ }^{0 *}$ indicate the transition state is associated with the bond breaking and increase in order.

Keywords: Viscosities, Apparent molar volumes, Mixed electrolytes, Aqueous solution.

\section{INTRODUCTION}

The studies of thermodynamic properties of aqueous mixed electrolytic solutions using the Mayer-MeMillian [1,2] theory as developed by Friedman and Anderson have been found to be useful in understanding the specific ion-ion interactions in solution Patil and coworkers [3,4] have determined viscosities of aqueous mixed electrolytic solutions for the systems. $\mathrm{KBr}-\mathrm{NaBr}$. $\mathrm{KBr}-\mathrm{Bu}{ }_{4} \mathrm{NBr}$. NaCl-NaBr and $\mathrm{NaCl}-\mathrm{Bu}{ }_{4} \mathrm{NBr}$ at various constant ionic strength with varying electrolyte mole fractions (y) at $25^{\circ} \mathrm{C}$.

It appears that studies on viscosities and apparent molar volume of bi-univalent mixed electrolytes in aqueous solution in relation to ion-ion and ion-solvent interaction are still lacking. With this aim, present study has been undertaken in aqueous solutions at different temperatures. The following bi-univalent mixed electrolytes have been used:

$\mathrm{CaCl}_{2}+\mathrm{BaCl}_{2}, \mathrm{NiCl}_{2}+\mathrm{BaCl}_{2}, \mathrm{MgCl}_{2}+\mathrm{BaCl}_{2}, \mathrm{MnCl}_{2}+\mathrm{CaCl}_{2}$, $\mathrm{CaCl}_{2}+\mathrm{MgCl}_{2}, \mathrm{NiCl}_{2}+\mathrm{MgCl}_{2}, \mathrm{MnCl}_{2}+\mathrm{NiCl}_{2}, \mathrm{NiCl}_{2}+\mathrm{CaCl}_{2}$, $\mathrm{NiCl}_{2}+\mathrm{SrCl}_{2}, \mathrm{Mg}\left(\mathrm{NO}_{3}\right)_{2}+\mathrm{Ca}\left(\mathrm{NO}_{3}\right)_{2}, \mathrm{Zn}\left(\mathrm{NO}_{3}\right)_{2}+\mathrm{Mg}\left(\mathrm{NO}_{3}\right)_{2}$, $\mathrm{Sr}\left(\mathrm{NO}_{3}\right)_{2}+\mathrm{Co}\left(\mathrm{NO}_{3}\right)_{2}, \mathrm{Co}\left(\mathrm{NO}_{3}\right)_{2}+\mathrm{Zn}\left(\mathrm{NO}_{3}\right)_{2}, \mathrm{BaCl}_{2}+\mathrm{MnCl}_{2}$, $\mathrm{BaCl}_{2}+\mathrm{CoCl}_{2}, \mathrm{NiCl}_{2}+\mathrm{CoCl}_{2}, \mathrm{SrCl}_{2}+\mathrm{CoCl}_{2}, \mathrm{CoCl}_{2}+\mathrm{MgCl}_{2}$ and $\mathrm{SrCl}_{2}+\mathrm{MgCl}_{2}$.
The title study has been undertaken in the light of the following aspects:

(1) Determination of densities and viscosities of aqueous solutions of above mentioned bi-univalent mixed electrolytes at different temperatures $(293.15,303.15$ and $313.15+0.01$ $\mathrm{K}$ ) as a function of fraction of the ionic strength due to the first electrolyte in the mixture of two electrolytes (here in after denoted by y) keeping the ionic strength constant at a particular value depending upon the solubility of the electrolytes;

(2) Analysis viscosity data in the light of Jones-Dole equation;

(3) Determination of apparent molar volume $\left(\phi_{v}\right)$ from the density data as a function of $y$, at different temperatures and calculation of the values of constants $\phi_{v}^{0}$ and $S_{v}$ of Masson's equation;

(4) Determination of free energies of activation for viscous flow $\Delta \mu_{1}{ }^{0 \text { \# }}$ and $\Delta \mu_{2}{ }^{\text {OH }}$ per mole of solvent and solute respectively and also the calculation of entropy of activation $\left(\Delta \mathrm{S}_{2}{ }^{0 *}\right)$ and enthalpy of activation $\left(\Delta \mathrm{H}_{2}{ }^{0+1}\right)$ of the bi-univalent mixed electrolytes solutions at different temperatures with a view to interpret the solution behaviour of mixed electrolytes; and

(5) Ascertaining structure-making or structure-breaking capacities of mixed electrolyte systems in aqueous solution. 


\section{EXPERIMENTAL}

All the bi-univalent electrolytes were of analytical reagent grade and were used after drying in a vacuum oven at $110^{\circ} \mathrm{C}$ for 10 to $12 \mathrm{~h}$. The standard stock solutions of these electrolytes were prepared in doubly distilled water (specific conductivity: $10^{-6} \mathrm{ohm}^{-1} \mathrm{~cm}^{-1}$ ) The solutions of mixed electrolytes of different composition with y varying in the range of 0.0 of 1.0 , were prepared by mixing requisite volume of the solutions of individual electrolytes, in a measuring flask keeping the ionic strength constant.

The densities and viscosities of aqueous solutions of mixed electrolytes were determined at different temperatures (293.15, 303.15 and $313.15 \pm 0.01 \mathrm{~K}$ ). The viscosity data were analyzed in the light of the modified form of Jones-Dole equation [5] as given blow:

Jones-Dole equation is

$$
\eta_{\text {rel }}=\frac{\eta}{\eta_{0}}=1+\mathrm{A} \sqrt{\mathrm{C}}+\mathrm{BC}
$$

$$
\text { or } \quad \frac{\left(\eta_{\text {rel }}-1\right)}{\sqrt{\mathrm{C}}}=\mathrm{A}+\mathrm{B} \sqrt{\mathrm{C}}
$$

In the case of solutions of mixed electrolytes (at a constant ionic strength) replacing $\mathrm{C}$ by y i.e. fraction of ionic strength due to the first electrolyte in the mixtures of two electrolytes in eqn. 3 , the Jones-Dole equation assumes the following modified form [6].

$$
\frac{\left(\eta_{\mathrm{rel}}-1\right)}{\sqrt{\mathrm{y}}}=\mathrm{A}+\mathrm{B} \sqrt{\mathrm{y}}
$$

Thus from the linear plots of $\left(\eta_{\text {rel }}-1\right) / \sqrt{ } \mathrm{C}$ and $\frac{\left(\eta_{\text {rel }}-1\right)}{\sqrt{\mathrm{y}}}$ versus $\sqrt{\mathrm{y}}$, the value of $\mathrm{A}$ and $\mathrm{B}$ can be obtained.

The apparent molar volume $\left(\phi_{v}\right)$ of aqueous solutions of bi-univalent mixed electrolyte systems was determined as a function of $\mathrm{y}$, at different temperatures using the following eqn. 4 [7]:

$$
\phi_{\mathrm{v}}=\frac{1000\left(\rho_{0}-\rho\right)}{\mathrm{C} \rho_{0}}+\frac{\bar{M}}{\rho_{0}}
$$

where $\rho_{0}$ and $\rho$ are the densities of solvent and solution respectively and $C$ is the molarity of the solution, $\bar{M}$ is the effective molecular weight of the mixed electrolyte system given by

$$
\bar{M}=\frac{n_{1} M_{1}+n_{2} M_{2}}{n_{1}+n_{2}}
$$

where $\mathrm{n}_{1}$ and $\mathrm{n}_{2}$ are the number of moles, $\mathrm{M}_{1}$ and $\mathrm{M}_{2}$ are the molecular weights of first and second electrolytes respectively. The variation of apparent molar volume $\left(\phi_{\mathrm{v}}\right)$ with the molar concentration of the electrolyte solution is governed by Masson's equation (eqn. 6) [8]

$$
\phi_{\mathrm{v}}=\phi_{\mathrm{v}}^{0}+\mathrm{S}_{\mathrm{v}} \sqrt{\mathrm{C}}
$$

In the present study, the modified form of this equation in terms of $\mathrm{y}$ is to be determined on the basis of the linearity or otherwise of $\Phi_{\mathrm{v}}$ versus $\sqrt{\mathrm{y}}$ plots $\Phi_{\mathrm{v}}$ versus y plots.

Free energies of activities of viscous flow $\Delta \mu_{2}{ }^{0 \#}$ and $\Delta \mu_{1}{ }^{0 \#}$ per mole of solute and solvent respectively were determined at different temperatures. The values of entropy and enthalpy of activation of viscous flow were calculated from the following equations:

$$
\begin{gathered}
\mathrm{d} \frac{\left(\Delta \mu_{2}^{0 \#}\right)}{\mathrm{dT}}=-\Delta \mathrm{S}_{2}^{0 \#} \\
\Delta \mathrm{H}_{2}^{0 \#}=\Delta \mu_{2}^{0 \#}+\mathrm{T} \Delta \mathrm{S}_{2}^{0 \#}
\end{gathered}
$$

The experimental data in regard to foregoing aspects of

\begin{tabular}{|c|c|c|c|c|c|c|c|}
\hline \multirow{2}{*}{ Mixed electrolyte system } & \multirow{2}{*}{$\begin{array}{c}\text { Ionic } \\
\text { strength (I) }\end{array}$} & \multicolumn{3}{|c|}{$\mathrm{A}\left(\mathrm{dm}^{3 / 2} \mathrm{~mol}^{-1 / 2}\right)$} & \multicolumn{3}{|c|}{$\mathrm{B}\left(\mathrm{dm}^{3} \mathrm{~mol}^{-1}\right)$} \\
\hline & & $293.15 \mathrm{~K}$ & $303.15 \mathrm{~K}$ & $313.51 \mathrm{~K}$ & $293.15 \mathrm{~K}$ & $303.15 \mathrm{~K}$ & $313.51 \mathrm{~K}$ \\
\hline $\mathrm{CaCl}_{2}+\mathrm{BaCl}_{2}$ & 3.0 & -0.0675 & -0.1551 & -0.198 & 0.527 & 0.5294 & 0.5438 \\
\hline $\mathrm{NiCl}_{2}+\mathrm{BaCl}_{2}$ & 3.0 & -0.3461 & -0.5698 & -0.62 & 0.3801 & 0.5104 & 0.6332 \\
\hline $\mathrm{MnCl}_{2}+\mathrm{CaCl}_{2}$ & 3.0 & -0.0772 & -0.1634 & -0.2036 & 0.7668 & 0.7983 & 0.5357 \\
\hline $\mathrm{BaCl}_{2}+\mathrm{CoCl}_{2}$ & 1.5 & -0.3276 & -0.4667 & -0.5761 & 0.2848 & 0.3849 & 0.4809 \\
\hline $\mathrm{NiCl}_{2}+\mathrm{CoCl}_{2}$ & 1.5 & 0.1451 & 0.0777 & 0.0646 & 0.1671 & 0.1875 & 0.1922 \\
\hline $\mathrm{SrCl}_{2}+\mathrm{CoCl}_{2}$ & 1.5 & -0.0711 & -0.1354 & -0.1491 & 0.5405 & 0.5548 & 0.5734 \\
\hline $\mathrm{CoCl}_{2}+\mathrm{MgCl}_{2}$ & 1.5 & -0.3809 & -0.6266 & -0.7107 & 0.4755 & 0.6366 & 0.7684 \\
\hline $\mathrm{MgCl}_{2}+\mathrm{BaCl}_{2}$ & 3.0 & 0.1287 & 0.1063 & 0.0802 & 0.294 & 0.3065 & 0.3137 \\
\hline $\mathrm{CaCl}_{2}+\mathrm{MgCl}_{2}$ & 3.0 & -0.0282 & -0.0417 & -0.0542 & 0.1878 & 0.1894 & 0.2139 \\
\hline $\mathrm{NiCl}_{2}+\mathrm{MgCl}_{2}$ & 3.0 & -0.2799 & -0.5497 & -0.6049 & 0.3898 & 0.5823 & 0.7007 \\
\hline $\mathrm{SrCl}_{2}+\mathrm{MgCl}_{2}$ & 1.5 & -0.2984 & -0.5531 & -0.5763 & 0.405 & 0.6146 & 0.6879 \\
\hline $\mathrm{Mg}\left(\mathrm{NO}_{3}\right)_{2}+\mathrm{Ca}\left(\mathrm{NO}_{3}\right)_{2}$ & 3.0 & -0.038 & -0.132 & -0.2071 & 0.5242 & 0.5361 & 0.547 \\
\hline $\mathrm{Zn}\left(\mathrm{NO}_{3}\right)_{2}+\mathrm{Mg}\left(\mathrm{NO}_{3}\right)_{2}$ & 3.0 & 0.3334 & 0.185 & 0.1599 & 0.369 & 0.3794 & 0.3875 \\
\hline $\mathrm{MnCl}_{2}+\mathrm{NiCl}_{2}$ & 3.0 & 0.0296 & 0.0207 & 0.0189 & 0.0557 & 0.3081 & 0.3564 \\
\hline $\mathrm{NiCl}_{2}+\mathrm{SrCl}_{2}$ & 3.0 & -0.3783 & -0.4859 & -0.5420 & 0.423 & 0.4273 & 0.4898 \\
\hline $\mathrm{NiCl}_{2}+\mathrm{CaCl}_{2}$ & 3.0 & 0.1188 & 0.0999 & 0.0929 & -0.2636 & -0.273 & -0.2812 \\
\hline $\mathrm{BaCl}_{2}+\mathrm{MnCl}_{2}$ & 1.5 & -0.5566 & -0.6147 & -0.6593 & 0.3687 & 0.5885 & 0.6937 \\
\hline
\end{tabular}
the present study have been presented in Tables 1-5.

\section{RESULTS AND DISCUSSION}

The densities and viscosities of aqueous solution of biunivalent mixed electrolytes have been determined at 293.15,

TABLE-1

VALUES OF COEFFICIENTS A AND B OF JONES-DOLE EQUATION FOR BI-UNIVALENT

MIXED ELECTROLYTE SYSTEMS IN AQUEOUS MEDIUM AT DIFFERENT TEMPERATURES 


\begin{tabular}{|c|c|c|c|c|c|c|c|}
\hline \multicolumn{8}{|c|}{$\begin{array}{l}\text { TABLE- } \\
\text { R VOLUN }\end{array}$} \\
\hline \multirow{2}{*}{ Mixed electrolyte system } & \multirow{2}{*}{$\begin{array}{c}\text { Ionic } \\
\text { strength (I) }\end{array}$} & \multicolumn{3}{|c|}{$\mathrm{V}_{\phi}^{0}\left(\mathrm{~cm}^{3} \mathrm{~mol}^{-1}\right)$} & \multicolumn{3}{|c|}{$\mathrm{S}_{\mathrm{v}}\left(\mathrm{cm}^{3} \mathrm{dm}^{3 / 2} \mathrm{~mol}^{-3 / 2}\right)$} \\
\hline & & $293.15 \mathrm{~K}$ & $303.15 \mathrm{~K}$ & $313.51 \mathrm{~K}$ & $293.15 \mathrm{~K}$ & $303.15 \mathrm{~K}$ & $313.51 \mathrm{~K}$ \\
\hline $\mathrm{CaCl}_{2}+\mathrm{BaCl}_{2}$ & 3.0 & 110.81 & 113.05 & 116.79 & -31.15 & -32.695 & -42.88 \\
\hline $\mathrm{NiCl}_{2}+\mathrm{BaCl}_{2}$ & 3.0 & 128.43 & 130.81 & 132.33 & -36.748 & -40.5 & -43.33 \\
\hline $\mathrm{MnCl}_{2}+\mathrm{CaCl}_{2}$ & 3.0 & 87.088 & 88.89 & 90.375 & -59.358 & -80.91 & -81.58 \\
\hline $\mathrm{BaCl}_{2}+\mathrm{CoCl}_{2}$ & 1.5 & 219.41 & 224.08 & 229.42 & -23.482 & -33.077 & -52.11 \\
\hline $\mathrm{NiCl}_{2}+\mathrm{CoCl}_{2}$ & 1.5 & 214.67 & 218.53 & 220.62 & 23.549 & 21.275 & 15.023 \\
\hline $\mathrm{SrCl}_{2}+\mathrm{CoCl}_{2}$ & 1.5 & 220.72 & 224.79 & 227.12 & -24.454 & -28.391 & -39.06 \\
\hline $\mathrm{CoCl}_{2}+\mathrm{MgCl}_{2}$ & 1.5 & 236.93 & 240.39 & 243.44 & -33.567 & -40.262 & 47.274 \\
\hline $\mathrm{MgCl}_{2}+\mathrm{BaCl}_{2}$ & 3.0 & 110.92 & 114.4 & 117.3 & 59.157 & 57.256 & 50.694 \\
\hline $\mathrm{CaCl}_{2}+\mathrm{MgCl}_{2}$ & 3.0 & 166.74 & 170.32 & 173.35 & -87.48 & -95.193 & -102.2 \\
\hline $\mathrm{NiCl}_{2}+\mathrm{MgCl}_{2}$ & 3.0 & 159.92 & 161.53 & 162.1 & -46.45 & -50.693 & -55.06 \\
\hline $\mathrm{SrCl}_{2}+\mathrm{MgCl}_{2}$ & 1.5 & 220.47 & 224.83 & 227.76 & -26.247 & -28.165 & -36.47 \\
\hline $\mathrm{Mg}\left(\mathrm{NO}_{3}\right)_{2}+\mathrm{Ca}\left(\mathrm{NO}_{3}\right)_{2}$ & 3.0 & 159.12 & 160.42 & 160.97 & -18.469 & -17.714 & -15.47 \\
\hline $\mathrm{Zn}\left(\mathrm{NO}_{3}\right)_{2}+\mathrm{Mg}\left(\mathrm{NO}_{3}\right)_{2}$ & 3.0 & 141.23 & 143.96 & 144.95 & 16.371 & 11.598 & 9.073 \\
\hline $\mathrm{Co}\left(\mathrm{NO}_{3}\right)_{2}+\mathrm{Zn}\left(\mathrm{NO}_{3}\right)_{2}$ & 3.0 & 259.03 & 262.62 & 265.34 & -7.234 & -18.562 & -19.51 \\
\hline $\mathrm{Sr}\left(\mathrm{NO}_{3}\right)_{2}+\mathrm{Co}\left(\mathrm{NO}_{3}\right)_{2}$ & 3.0 & 143.63 & 144.13 & 144.33 & -38.751 & -34.558 & -32.24 \\
\hline $\mathrm{MnCl}_{2}+\mathrm{NiCl}_{2}$ & 3.0 & 75.014 & 77.273 & 78.651 & 50.207 & 47.542 & $37 . .948$ \\
\hline $\mathrm{NiCl}_{2}+\mathrm{SrCl}_{2}$ & 3.0 & 122.83 & 123.75 & $124 . .800$ & -13.062 & -12.441 & -11.63 \\
\hline $\mathrm{NiCl}_{2}+\mathrm{CaCl}_{2}$ & 3.0 & 67.931 & 69.299 & 70.764 & 43.282 & 38.129 & 30.679 \\
\hline $\mathrm{BaCl}_{2}+\mathrm{MnCl}_{2}$ & 1.5 & 240.61 & 241.29 & 242.16 & -47.48 & -46.551 & -45.51 \\
\hline
\end{tabular}

303.15 and $313.15 \pm 0.01 \mathrm{~K}$ as a function of $\mathrm{y}$, the fraction of ionic strength due to first electrolyte in the mixture of two electrolytes, keeping the ionic strength constant (Tables $1-5)$.

\begin{tabular}{|c|c|c|c|c|}
\hline $\begin{array}{l}\text { VALUES OF } \\
\text { ELECTRC } \\
\text { MEDIUM }\end{array}$ & $\begin{array}{l}\text { TAB } \\
\mu_{2}{ }^{0 \#} \text { FOR I } \\
\text { YTE SYS } \\
\text { DIFFER }\end{array}$ & $\begin{array}{l}\text { E-3 } \\
\text { [-UNIVAI } \\
\text { EMS IN } A \\
\text { NT TEMP }\end{array}$ & $\begin{array}{l}\text { NT MIXE } \\
\text { UEOUS } \\
\text { ATURES }\end{array}$ & \\
\hline & Ionic & & $2^{0 \# 1}(\mathrm{~kJ} \mathrm{mo}$ & \\
\hline $\begin{array}{l}\text { system } \\
\text { silte }\end{array}$ & $\begin{array}{l}\text { strength } \\
\text { (I) }\end{array}$ & $\begin{array}{c}293.15 \\
\text { K }\end{array}$ & $\begin{array}{c}303.15 \\
\mathrm{~K}\end{array}$ & $\begin{array}{c}313.51 \\
\mathrm{~K}\end{array}$ \\
\hline $\mathrm{CaCl}_{2}+\mathrm{BaCl}_{2}$ & 3.0 & 83.790 & 87.066 & 92.222 \\
\hline $\mathrm{NiCl}_{2}+\mathrm{BaCl}_{2}$ & 3.0 & 65.272 & 86.826 & 107.283 \\
\hline $\mathrm{MnCl}_{2}+\mathrm{CaCl}_{2}$ & 3.0 & 112.996 & 121.677 & 130.323 \\
\hline $\mathrm{BaCl}_{2}+\mathrm{CoCl}_{2}$ & 1.5 & 65.732 & 95.783 & 113.022 \\
\hline $\mathrm{NiCl}_{2}+\mathrm{CoCl}_{2}$ & 1.5 & 49.183 & 54.106 & 56.669 \\
\hline $\mathrm{SrCl}_{2}+\mathrm{CoCl}_{2}$ & 1.5 & 100.470 & 54.106 & 56.669 \\
\hline $\mathrm{CoCl}_{2}+\mathrm{MgCl}_{2}$ & 1.5 & 93.876 & 119.847 & 142.675 \\
\hline $\mathrm{MgCl}_{2}+\mathrm{BaCl}_{2}$ & 3.0 & 52.312 & 56.179 & 59.272 \\
\hline $\mathrm{CaCl}_{2}+\mathrm{MgCl}_{2}$ & 3.0 & 45.503 & 47.650 & 53.022 \\
\hline $\mathrm{NiCl}_{2}+\mathrm{MgCl}_{2}$ & 3.0 & 70.901 & 101.199 & 121.242 \\
\hline $\mathrm{SrCl}_{2}+\mathrm{MgCl}_{2}$ & 1.5 & 82.122 & 114.527 & 128.828 \\
\hline $\mathrm{Mg}\left(\mathrm{NO}_{3}\right)_{2}+\mathrm{Ca}\left(\mathrm{NO}_{3}\right)_{2}$ & 3.0 & 89.941 & 94.604 & 99.022 \\
\hline $\mathrm{Zn}\left(\mathrm{NO}_{3}\right)_{2}+\mathrm{Mg}\left(\mathrm{NO}_{3}\right)_{2}$ & 3.0 & 66.546 & 70.463 & 73.832 \\
\hline $\mathrm{Co}\left(\mathrm{NO}_{3}\right)_{2}+\mathrm{Zn}\left(\mathrm{NO}_{3}\right)_{2}$ & 3.0 & 69.047 & 72.674 & 76.242 \\
\hline $\mathrm{Sr}\left(\mathrm{NO}_{3}\right)_{2}+\mathrm{Co}\left(\mathrm{NO}_{3}\right)_{2}$ & 3.0 & 168.605 & 179.032 & 186.746 \\
\hline $\mathrm{MnCl}_{2}+\mathrm{NiCl}_{2}$ & 3.0 & 38.431 & 51.226 & 59.854 \\
\hline $\mathrm{NiCl}_{2}+\mathrm{SrCl}_{2}$ & 3.0 & 71.478 & 74.103 & 77.075 \\
\hline $\mathrm{NiCl}_{2}+\mathrm{CaCl}_{2}$ & 3.0 & 42.393 & 45.221 & 47.858 \\
\hline $\mathrm{BaCl}_{2}+\mathrm{MnCl}_{2}$ & 1.5 & 79.938 & 113.183 & 131.727 \\
\hline
\end{tabular}

TABLE-4

FREE ENERGY OF ACTIVATION, $\Delta \mu_{1}^{0 \#}\left(\mathrm{~kJ} \mathrm{~mol}^{-1}\right)$ FOR WATER AT DIFFERENT TEMPERATURE

\begin{tabular}{ccc}
\hline $293.15 \mathrm{~K}$ & $303.15 \mathrm{~K}$ & $313.15 \mathrm{~K}$ \\
\hline 20.58 & 20.71 & 20.85 \\
\hline
\end{tabular}

The viscosity data have been analyzed in the light of modified form of Jones-Dole equation as under:

$$
\frac{\left(\eta_{\text {rel }}-1\right)}{\sqrt{\mathrm{y}}}=\mathrm{A}+\mathrm{B} \sqrt{\mathrm{y}}
$$

The values of coefficients A and B have been obtained from the linear plots of $\left(\eta_{\mathrm{rel}}-1\right) / \sqrt{\mathrm{y}}$ versus $\sqrt{\mathrm{y}}$ by the method of least squares and listed in Table-1, shows that the values of $\mathrm{A}$ are negative for all the mixed electrolyte systems except for the mixed systems: $\mathrm{NiCl}_{2}+\mathrm{CoCl}_{2}, \mathrm{MgCl}_{2}+\mathrm{BaCl}_{2}, \mathrm{Zn}\left(\mathrm{NO}_{3}\right)_{2}$ $+\mathrm{Mg}\left(\mathrm{NO}_{3}\right)_{2}, \mathrm{MnCl}_{2}+\mathrm{NiCl}_{2}$ and $\mathrm{NiCl}_{2}+\mathrm{CaCl}_{2}$, for which the values are positive. From this it follows that ion-ion interaction are weak in aqueous solution of all the mixed bi-univalent electrolytes except for the mixed systems: $\mathrm{NiCl}_{2}+\mathrm{CoCl}_{2}$, $\mathrm{MgCl}_{2}+\mathrm{BaCl}_{2}, \mathrm{Zn}\left(\mathrm{NO}_{3}\right)_{2}+\mathrm{Mg}\left(\mathrm{NO}_{3}\right)_{2}, \mathrm{MnCl}_{2}+\mathrm{NiCl}_{2}$ and $\mathrm{NiCl}_{2}+\mathrm{CaCl}_{2}$, for which the ion-ion interaction are strong.

The values of coefficients B are, however positive for the entire mixed bi-univalent electrolyte, which indicate the presence of strong ion-solvent interaction. The data of apparent molar volume $\left(\Phi_{\mathrm{v}}\right)$ as a function of $\mathrm{y}$, have been analyzed in the light of the modified form of Masson's equation:

$$
\phi_{\mathrm{v}}=\phi_{\mathrm{v}}^{0}+\mathrm{S}_{\mathrm{v}} \mathrm{y}
$$

From the linear plots of $\Phi_{\mathrm{v}}$ versus y, the values of $\Phi_{\mathrm{v}}{ }^{0}$ and $\mathrm{S}_{\mathrm{v}}$ have been obtained by the method of least squares and presented in the Table-2. It is seen that the values of $\Phi_{\mathrm{v}}{ }^{0}$ are positive and large. The positive values of $\Phi_{\mathrm{v}}{ }^{0}$ indicate the presence of strong ion-solvent interaction [7]. It may be attributed to increased solvation of ions in the mixes electrolyte systems. Further with the rice of temperature the values of $\Phi_{\mathrm{v}}{ }^{0}$ tend to increase, which shows the ion-solvent interaction are rendered increasingly stronger at elevated temperatures. This may be ascribed to the increased salvation of ions with the rice of temperature.

A perusal of Table- 2 shows that the values of $S_{v}$ are negative for the following mixed bi-univalent electrolyte: 
VALUES OF ENTROPY OF ACTIVATION $\left(\mathrm{T} \Delta \mathrm{S}_{2}{ }^{\circ *}\right)$ AND ENTHALPY OF ACTIVATION $\left(\Delta \mathrm{H}_{2}{ }^{0 *}\right)$ FOR THE AQUEOUS SOLUTIONS OF BI-UNIVALENT MIXED ELECTROLYTE SYSTEMS AT DIFFERENT TEMPERATURES

\begin{tabular}{|c|c|c|c|c|c|c|c|}
\hline \multirow{2}{*}{ Mixed electrolyte system } & \multirow{2}{*}{$\begin{array}{c}\text { Ionic } \\
\text { strength (I) }\end{array}$} & \multicolumn{3}{|c|}{$\mathrm{T} \Delta \mathrm{S}_{2}{ }^{0 \#}\left(\mathrm{~kJ} \mathrm{~mol}^{-1}\right)$} & \multicolumn{3}{|c|}{$\Delta \mathrm{H}_{2}^{0 \#}\left(\mathrm{~kJ} \mathrm{~mol}^{-1}\right)$} \\
\hline & & $293.15 \mathrm{~K}$ & $303.15 \mathrm{~K}$ & $313.51 \mathrm{~K}$ & $293.15 \mathrm{~K}$ & $303.15 \mathrm{~K}$ & $313.51 \mathrm{~K}$ \\
\hline $\mathrm{CaCl}_{2}+\mathrm{BaCl}_{2}$ & 3.0 & -123.59 & -127.81 & -132.03 & 207.38 & 214.88 & 224.25 \\
\hline $\mathrm{NiCl}_{2}+\mathrm{BaCl}_{2}$ & 3.0 & -615.77 & -636.38 & -657.79 & 681.05 & 723.61 & 765.07 \\
\hline $\mathrm{MnCl}_{2}+\mathrm{CaCl}_{2}$ & 3.0 & -253.99 & -262.65 & -271.31 & 366.98 & 384.33 & 401.64 \\
\hline $\mathrm{BaCl}_{2}+\mathrm{CoCl}_{2}$ & 1.5 & -693.14 & -716.79 & -740.43 & 758.87 & 812.57 & 853.45 \\
\hline $\mathrm{NiCl}_{2}+\mathrm{CoCl}_{2}$ & 1.5 & -109.72 & -113.47 & -117.21 & 158.91 & 167.57 & 173.88 \\
\hline $\mathrm{SrCl}_{2}+\mathrm{CoCl}_{2}$ & 1.5 & -173.32 & -179.24 & -185.15 & 273.80 & 285.42 & 297.42 \\
\hline $\mathrm{CoCl}_{2}+\mathrm{MgCl}_{2}$ & 1.5 & -715.27 & -739.67 & -764.07 & 809.15 & 859.42 & 906.15 \\
\hline $\mathrm{MgCl}_{2}+\mathrm{BaCl}_{2}$ & 3.0 & -102.02 & -105.50 & -108.98 & 154.33 & 161.67 & 168.25 \\
\hline $\mathrm{CaCl}_{2}+\mathrm{MgCl}_{2}$ & 3.0 & -110.21 & -113.97 & -117.73 & 155.72 & 161.62 & 170.75 \\
\hline $\mathrm{NiCl}_{2}+\mathrm{MgCl}_{2}$ & 3.0 & -737.28 & -763.05 & -788.22 & 808.78 & 864.25 & 909.46 \\
\hline $\mathrm{SrCl}_{2}+\mathrm{MgCl}_{2}$ & 1.5 & -684.60 & -707.95 & -731.31 & 766.32 & 822.48 & 860.13 \\
\hline $\mathrm{Mg}\left(\mathrm{NO}_{3}\right)_{2}+\mathrm{Ca}\left(\mathrm{NO}_{3}\right)_{2}$ & 3.0 & -133.10 & -137.64 & -142.18 & 223.04 & 232.25 & 241.20 \\
\hline $\mathrm{Zn}\left(\mathrm{NO}_{3}\right)_{2}+\mathrm{Mg}\left(\mathrm{NO}_{3}\right)_{2}$ & 3.0 & -106.79 & -110.43 & -114.08 & 173.34 & 180.90 & 187.91 \\
\hline $\mathrm{Sr}\left(\mathrm{NO}_{3}\right)_{2}+\mathrm{Co}\left(\mathrm{NO}_{3}\right)_{2}$ & 3.0 & -265.91 & -274.91 & -284.05 & 434.51 & 454.01 & 470.79 \\
\hline $\mathrm{MnCl}_{2}+\mathrm{NiCl}_{2}$ & 3.0 & -314.01 & -324.72 & -335.43 & 352.44 & 375.95 & 395.29 \\
\hline $\mathrm{NiCl}_{2}+\mathrm{SrCl}_{2}$ & 3.0 & -82.04 & -84.84 & -87.64 & 153.52 & 158.94 & 164.71 \\
\hline $\mathrm{NiCl}_{2}+\mathrm{CaCl}_{2}$ & 3.0 & -80.10 & -82.83 & -85.56 & 122.49 & 128.05 & 133.42 \\
\hline $\mathrm{BaCl}_{2}+\mathrm{MnCl}_{2}$ & 1.5 & -759.11 & -785.00 & -810.90 & 839.04 & 898.19 & 942.62 \\
\hline
\end{tabular}

$\mathrm{CaCl}_{2}+\mathrm{BaCl}_{2}, \mathrm{NiCl}_{2}+\mathrm{BaCl}_{2}, \mathrm{MgCl}_{2}+\mathrm{BaCl}_{2}, \mathrm{MnCl}_{2}+\mathrm{CaCl}_{2}$, $\mathrm{CaCl}_{2}+\mathrm{MgCl}_{2}, \mathrm{NiCl}_{2}+\mathrm{MgCl}_{2}, \mathrm{MnCl}_{2}+\mathrm{NiCl}_{2}, \mathrm{NiCl}_{2}+\mathrm{CaCl}_{2}$ $\mathrm{NiCl}_{2}+\mathrm{SrCl}_{2}, \mathrm{Mg}\left(\mathrm{NO}_{3}\right)_{2}+\mathrm{Ca}\left(\mathrm{NO}_{3}\right)_{2}, \mathrm{Zn}\left(\mathrm{NO}_{3}\right)_{2}+\mathrm{Mg}\left(\mathrm{NO}_{3}\right)_{2}$, $\mathrm{Sr}\left(\mathrm{NO}_{3}\right)_{2}+\mathrm{Co}\left(\mathrm{NO}_{3}\right)_{2}, \mathrm{Co}\left(\mathrm{NO}_{3}\right)_{2}+\mathrm{Zn}\left(\mathrm{NO}_{3}\right)_{2}, \mathrm{BaCl}_{2}+\mathrm{MnCl}_{2}$ $\mathrm{BaCl}_{2}+\mathrm{CoCl}_{2}, \mathrm{NiCl}_{2}+\mathrm{CoCl}_{2}, \mathrm{SrCl}_{2}+\mathrm{COCl}_{2}, \mathrm{CoCl}_{2}+\mathrm{MgCl}_{2}$ and $\mathrm{SrCl}_{2}+\mathrm{MgCl}_{2}$.

The negative values of $S_{v}$ for the above system indicate the presence of weak ion-ion interactions in the aqueous solution of these mixed bi-univalent electrolytes. On the other hand the positive values of $S_{\mathrm{v}}$ suggest the presence of strong ion-ion interaction in the aqueous solution of the following mixed bi-univalent electrolytes:

$$
\begin{gathered}
\mathrm{NiCl}_{2}+\mathrm{CoCl}_{2}, \mathrm{MgCl}_{2}+\mathrm{BaCl}_{2}, \mathrm{Zn}\left(\mathrm{NO}_{3}\right)_{2}+\mathrm{Mg}\left(\mathrm{NO}_{3}\right)_{2}, \\
\mathrm{MnCl}_{2}+\mathrm{NiCl}_{2} \text { and } \mathrm{NiCl}_{2}+\mathrm{CaCl}_{2}
\end{gathered}
$$

Free energies of activation for viscous flow: The free energies of activation of viscous flow, $\Delta \mu_{1}{ }^{0 \#}$ and $\Delta \mu_{2}{ }^{0 \#}$ per mole of solvent (water) and solute (mixed bi-univalent electrolytes) respectively are presented in the Tables $3 \mathrm{~A}$ and $3 \mathrm{~B}$, respectively. It is seen that the values of $\Delta \mu_{2}{ }^{0 \#}$ for the aqueous solutions of all the bi-univalent mixed electrolyte are positive. Further the values of $\Delta \mu_{2}{ }^{0 \#}$ are much larger as compared to those of $\Delta \mu_{1}{ }^{0 \#}$ and thus $\left(\Delta \mu_{2}{ }^{0 \#}-\Delta \mu_{1}{ }^{0 \#}\right)>0$. From this it follows that in aqueous solution all the mixed electrolytes under discussion are structure makers [9-11].

The entropy and enthalpy of activation of viscous flow for the aqueous solution of mixed bi-univalent electrolytes have been calculated and the values have been listed in Table- 4 . It is seen that in each case the values of $\mathrm{T} \Delta \mathrm{S}_{2}{ }^{0 \#}$ are negative and those of $\Delta \mathrm{H}_{2}{ }^{0 \#}$ are positive and thus $\Delta \mathrm{H}_{2}{ }^{0 \#}>\mathrm{T} \Delta \mathrm{S}_{2}{ }^{0 \#}$. This suggests that ion-solvent interactions for the mixed electrolyte systems, under discussion are nearly complete in the ground state. Further the positive values of $\Delta \mathrm{H}_{2}{ }^{0 \#}$ and negative values of $\mathrm{T} \Delta \mathrm{S}_{2}{ }^{0 \#}$ indicate that the transition state is associated with bond breaking and increase in order [12].

\section{Conclusion}

From the volumetric and viscometric studies reported in this paper, it has been concluded that the identical results are obtained. From both these studies with regard to ion-solvent and ion-ion interaction in aqueous solution of mixed biunivalent electrolyte.

\section{ACKNOWLEDGEMENTS}

Thanks are due to Head of Department of Chemistry and Principal, Agra College, Agra for providing necessary facilities.

\section{REFERENCES}

1. H.L. Friedman and P.S. Ramanathan, J. Phys. Chem., 74, 3756 (1970); https://doi.org/10.1021/j100715a009.

2. H.L. Andersan and R.H. Wood, ed.: F. Frank, Water: A Comprehensive Treatise, Plenum, New York, vol. III, Chap. 2 (1973).

3. K.J. Patil, S.M. Manwatkar and S.S. Dhondge, Indian J. Chem., 33A, 4 (1994).

4. K.J. Patil, S.M. Manwatkar and S.S. Dhondge, Indian J. Chem., 34A, 950 (1995)

5. G. Jones and M. Dole, J. Am. Chem. Soc., 51, 2950 (1929); https://doi.org/10.1021/ja01385a012.

6. D. Gautam and M. Singh, J. Indian Chem. Soc., 84, 876 (2007).

7. J.D. Panday and Y. Akhtar, Indian J. Chem., 36A, 614 (1997)

8. D.O. Masson, Philos. Mag., 8, 218 (1929); https://doi.org/10.1080/14786440808564880.

9. A. Ali, A.K. Nain, N. Kumar and M. Ibrahim, Proc. Indian Acad. Sci. Chem. Sci., 114, 495 (2002); https://doi.org/10.1007/BF02704193.

10. D. Feakins, D.J. Freemantle and K.G. Lawrence, J. Chem. Soc., Faraday Trans. I, 70, 795 (1974); https://doi.org/10.1039/f19747000795.

11. A.N. Kannapan and V. Rajendran, Indian J. Phys., B66, 135 (1992).

12. M.L. Parmar, D.K. Dhiman and R.C. Thakur, Indian J. Chem., 41A, 2032 (2002). 